\title{
MĘŻCZYZNA W SFERZE PRYWATNEJ - FIKCJA CZY RZECZYWISTOŚĆ?
}

\section{WPROWADZENIE}

Ostatnie 50 lat przyniosło dużo zmian zarówno w sferze publicznej, jak i prywatnej. Znaczaco zwiększa się udział kobiet w rynku pracy, jednak nie towarzyszy temu równie szybki wzrost zaangażowania mężczyzn w prace domowe i opiekę nad dziećmi czy osobami starszymi. W większości przypadków kobiety nadal ponosza główną odpowiedzialność za zajmowanie się dziećmi oraz pracę $\mathrm{w}$ gospodarstwie domowym, nawet w rodzinach, w których oboje partnerzy pracuja w pełnym wymiarze godzin.

Problem godzenia życia zawodowego i rodzinnego od zawsze był więc problemem kobiet. Wręcz, jak piszą Iwona Chmura-Rutkowska i Joanna Ostrouch, problem godzenia ról zawodowych i rodzinnych był i nadal jest definiowany jako specyficznie kobiecy ${ }^{1}$. W momencie kiedy kobiety weszły na rynek pracy, okazało się że nikt nie odciążył ich w rolach rodzinnych. Rozwój kariery zawodowej wiązał się więc z koniecznością godzenia jej z życiem rodzinnym. Przez dziesięciolecia funkcjonował swoisty model kobiety pracującej, która po zakończeniu pracy zawodowej „przechodziła” do wypełniania obowiazków rodzinnych - starając się zaspokoić wszystkie potrzeby dzieci i męża (female double burden ${ }^{2}$ ). Marjorie Hansen Shevitz dla podkreślenia wielości pełnionych ról nazwała ją nawet superkobieta ${ }^{3}$. Jednak, jak powszechnie wiadomo, superman jest postacią fikcyjna, tak samo nie istnieje w rzeczywistości superwoman, gdyż w normalnych warunkach idealne wypełnianie ról zawodowych i rodzinnych jest po prostu niemożliwe.

Pomimo tych przeciwności kobiety nie zrezygnowały z kariery zawodowej. Co więcej, od dziesiątek lat nieustannie dążą do tego, żeby ich sytuacja poprawiła się: żeby ktoś zauważył ogrom pracy, którą wykonują każdego dnia zarówno w miejscu zatrudnienia, jak i w domu. Równocześnie coraz częściej domagają się, żeby ktoś im pomógł w wypełnianiu codziennych obowiązków, nie lekceważąc przy tym żadnego rodzaju pracy, której się poświęcaja.

${ }^{1}$ I. Chmura-Rutkowska, J. Ostrouch, Mężczyźni na przełęczy życia: studium socjopedagogiczne, OW „Impuls”, Kraków 2007, s. 102.

${ }^{2}$ A. Leira, Working Parents and the Walfare State: Family Change and Policy Reform in Scandinavia, CUP, Cambridge 2002, s. 4-5.

${ }^{3}$ M. Hansen Shaevitz, The Superwoman Syndrome, Warner Communications Company, New York 1984, s. 15. 
Po drugiej stronie niniejszych rozważań mamy natomiast mężczyzn: mężów, partnerów, ojców, których problem godzenia życia zawodowego i rodzinnego nie dotyczył nigdy w takim samym stopniu co kobiety. Od tysięcy lat główna sfera ich aktywności była sfera publiczna i tam poszukiwali swojego miejsca. Nie oznacza to oczywiście, że sprawy „domu” w ogóle ich nie zajmowały, ponieważ nawet jeśli nie musieli oni rezygnować z pracy, czy ograniczać swojej aktywności publicznej (jak robiły to kobiety), to w dużej mierze uczestniczyli w trudnych decyzjach kobiet związanych z tym aspektem. Mimo że ich główna aktywność skierowana była do sfery publicznej, to w dalszym ciagu uczestniczyli w wychowaniu dzieci, tak samo dotykały ich problemy rodzinne. Nie ulega jednak wątpliwości, że kobiety musiały z tymi problemami borykać się o wiele częściej niż ich mężowie czy partnerzy.

Niemniej trzecie tysiąclecie wywróciło utarte schematy do góry nogami. Wraz z upowszechnianiem się partnerskiego modelu rodziny i jednoczesnym odchodzeniem od modelu tradycyjnego, okazało się, że wśród mężczyzn także może występować problem godzenia życia zawodowego i rodzinnego. Można bowiem spotkać coraz więcej mężczyzn (co jeszcze 50 lat temu było nie do pomyślenia w zachodnim kręgu kulturowym), którzy opiekę nad małym dzieckiem preferują ponad karierę zawodowa albo staraja się łączyć obydwie te sfery na zmianę z matką dziecka.

Wiele napisano na temat procesu wchodzenia kobiet na rynek pracy, wiele napisano na temat przyczyn tego zjawiska, jak również dokładnie przyjrzano się barierom, na które kobiety ciagle trafiają ${ }^{4}$. O zaangażowaniu się mężczyzn w sferze prywatnej przy jednoczesnym wykonywaniu obowiązków zawodowych nie wiemy natomiast za dużo5. Celem niniejszego artykułu jest odpowiedź na podstawie dostępnych danych i opracowań naukowych przedmiotu na pytanie, w jakim stopniu polscy mężczyźni angażują się w sferę prywatną i jak wygląda $\mathrm{z}$ ich perspektywy problem godzenia życia zawodowego i rodzinnego.

\section{PODŁOŻE TEORETYCZNE}

W literaturze przedmiotu istnieje wiele koncepcji, które opisują zależność między „praca” a „rodzina”.6. Warto zasygnalizować współwystępowanie co najmniej czterech, najczęściej wykorzystywanych ujęć. Pierwsze z nich odwołuje

${ }^{4}$ Por. np. J. Mazur-Łuczak, Kobiety na rynku pracy, WN WSNHiD, Poznań 2010; M. Gawrycka, J. Wasilczuk, P. Wiech (red.), Szklany sufit i ruchome schody: kobiety na rynku pracy, CeDeWu Warszawa 2007; B. Kalinowska-Nawrotek, Dyskryminacja kobiet na polskim rynku pracy, Wyd. AE, Poznań 2005; E. Lisowska, Przedsiębiorczość kobiet w Polsce na tle krajów Europy Środkowej $i$ Wschodniej, SGH, Warszawa 2001; A. Titkow (red.), Szklany sufit: bariery i ograniczenia karier kobiet: monografia zjawiska, Fundacja Instytut Spraw Publicznych, Warszawa 2003, a także wiele innych prac.

${ }^{5}$ Dlatego szczególnie warte są uwagi prace: I. Chmura-Rutkowska, J. Ostrouch, Mężczyźni na przełęczy życia: studium socjopedagogiczne, Kraków 2007, czy J. Ostrouch-Kamińska, Rodzina partnerska jako relacja wspótzależnych podmiotów: studium socjopedagogiczne narracji rodziców przeciażonych rolami, Kraków 2011.

${ }^{6}$ M. Pitt-Catsouphes, E. Kossek, S. Sweet, Charting New Territory: Advancing Multi-Disciplinary Perspectives, Methods and Approaches in the Study of Work and Family, w: M. Pitt-Catsouphes, E. E. Kossek, S. Sweet (red.), The Work and Family Handbook, Routledge 2005, s. 1-16. 
się do takich określeń, jak: godzenie życia zawodowego i rodzinnego (reconciliation of work and family life $)^{7} \mathrm{w}$ celu podkreślenia konieczności łączenia i koordynowania różnych obowiązków, wymagań i aktywności związanych z wypełnianiem ról w domu i w pracy. Druga koncepcja opiera się na konflikcie ról rodzinnych i zawodowych ${ }^{8}$ czy też przeciwstawia pracę rodzinie i rodzinę pracy ${ }^{9}$. Konflikt wynika z konieczności równoległego wypełniania różnych ról społecznych i zawodowych, których wymagania są nawzajem sprzeczne (np. konieczność jednoczesnego przebywania w domu w celu opieki nad dzieckiem i w pracy w celu realizacji zadań zleconych przez pracodawcę). Trzecie podejście odnosi się do balansowania między rodziną a pracą (work-family balance $)^{10}$. Badacze, którzy wykorzystują tę koncepcję opisują ją jako sytuację, w której występuje niski poziom konfliktu na linii praca-dom i wysoki poziom godzenia życia rodzinnego i zawodowego (reconciliation). Ostatnia z koncepcji, o której chcę wspomnieć (co nie oznacza, że lista jest wyczerpana), to koncepcja zaproponowana przez Sue Campbell Clark ${ }^{11}$ i Blake'a E. Ashfortha ${ }^{12}$. Proponują oni wyjaśnienie relacji pomiędzy życiem rodzinnym a zawodowym, zwracając naszą szczególną uwagę na granicę między pracą i rodzina. Stąd mówimy o „teorii granicy” (work-family border theory), która opisuje problem zacierania granic między życiem zawodowym i rodzinnym. Rozważania przedstawione w tym artykule najbliższe są trzeciej z przedstawionych koncepcji.

\section{OJCOSTWO W MIEJSCU PRACY}

Przez setki (a nawet tysiące lat) świat „zachodni” funkcjonował najczęściej wedle tradycyjnego podziału, w którym sfera publiczna (poza domem) należała do aktywności męskiej, a sfera prywatna - do aktywności kobiecej. Obydwie te sfery pozostawały ze sobą w definicyjnym, funkcjonalnym i pragmatycznym związku, choć oczywiście były od tego wyjątki. Niemniej w czasie, gdy mąż pracował i zapewniał rodzinie środki finansowe, żona zajmowała się domem, wychowywaniem dzieci i opieką nad osobami zależnymi. Podział ról był bardzo wyraźny. W praktyce oznaczało to najczęściej wykluczenie kobiet ze spraw

${ }^{7}$ S. Demetriades, M. Meixner, A Barry, Reconciliation of Work and Family Life and Collective Bargaining in the European Union: An Analysis of EIRO Articles, Report, European Foundation for the Improvement of Living and Working Conditions, Dublin 2006.

8 W. R. Boswell, J. B. Olson-Buchanan, The Use of Communication Technologies after Hours: The Role of Work Attitudes and Work-Life Conflict, „Journal of Management” 33, 2007, s. 592-610.

${ }^{9}$ E. Kelly et al., Getting There from Here: Research on the Effects of Work-Family Initiatives on Work-Family Conflict and Business Outcomes, "The Academy of Management Annals” 2(1), 2008, s. 305-349.

${ }^{10}$ M. Ackelsberg et al., Remembering the "Life" in Academic Life: Finding a Balance between Work and Personal Responsibilities in the Academy, 2004, PSOnline www.apsanet.org (dostęp: 20.05.2013).

${ }^{11}$ S. C. Clark, Work / Family Border Theory: A New Theory of Work / Family Balance, „Human Relations" 53, 2000, s. 747-770.

12 B. E. Ashforth, G. E. Kreiner, M. Fugate, All in a Day's Work: Boundaries and Micro Role Transitions, „Academy of Management Review” 25, 2000, s. 472-491. 
związanych z życiem publicznym, a z kolei mężczyźni nie angażowali się w sprawy „domowe”. Zasadę tę utrwalały zróżnicowane wzorce wychowawcze stosowane w rodzinie: inne wobec chłopców, a inne wobec dziewczynek. Relacje między tymi sferami określane były mianem „kontraktu płci”. Zdefiniowano go jako „zespół jawnych i ukrytych zasad, które w danym społeczeństwie określają relacje między płciami, przypisują kobietom i mężczyznom inny zakres pracy, obowiązków i powinności, określając jednocześnie ich wartość i prestiż z nimi związany"13. Ale, jak pisze Małgorzata Fuszara, obecnie mamy do czynienia z nowym kontraktem płci ${ }^{14}$. Jedna z jego konsekwencji są m.in. zmiany w odniesieniu do ról zawodowych i rodzinnych mężczyzn.

Przyjmuje się, że pierwszy najważniejszy moment zmian w sferze zawodowej mężczyzn wiąże się z rewolucją przemysłowa. Wymusiła ona bowiem proces przechodzenia mężczyzn z pracy na roli do pracy w przemyśle. Znaczenie, jakie nadała pracy rewolucja przemysłowa, sprawiło, że praca zawodowa i aktywność w sferze publicznej stały się istotą tożsamości mężczyzny, a rodzina została zepchnięta na drugi plan. Tak więc wraz $\mathrm{z}$ masową industrializacją i biurokratyzacją coraz mniej mężczyzn utrzymywało się z pracy w rolnictwie i coraz więcej czasu spędzało poza domem. Kobieta została więc obarczona wszystkimi obowiązkami związanymi ze sfera prywatną ${ }^{15}$.

Przez większość wieku XIX i prawie cały XX praca poza domem była istotal wyznacznikiem męskiej tożsamości. Jednak pod koniec XX w., wraz z ogromnym postępem techniki i technologii, doszło do kolejnych zmian o charakterze społecznym. Jak pisze Krzysztof Arcimowicz: „siła fizyczna przestaje być głównym wyznacznikiem męskości, a dostęp do Internetu zmienił oblicze świata [...]"16. Rewolucja elektroniczna sprawiła, że wprawdzie sukces w pracy zawodowej był nadal ważnym elementem tożsamości męskiej, ale sama praca przestała być jej stotą. Czas wolny stał się ważniejszy niż czas pracy. Nie oznaczało to oczywiście automatycznie, że ten nowo zyskany czas wolny mężczyźni od razu w całości przeznaczą na rodzinę, ale większość z nich zyskała przynajmniej taką możliwość.

Należy pamiętać, że pojawiające się coraz częściej kryzysy gospodarcze sprawiaja, że praca jest bardzo cennym dobrem i wielu pracowników za wszelka cenę nie chce jej stracić. W dodatku pracodawcy uważaja, że życie rodzinne pracowników nie powinno w żaden sposób zakłócać przebiegu pracy w firmie. O ile dopuszczaja takie sytuacje w odniesieniu do kobiet, o tyle w przypadku mężczyzn jest to czymś niewyobrażalnym.

Wynika to z tego, że ojcostwo w miejscu pracy jest niewidoczne, w przeciwieństwie do macierzyństwa, które pod wpływem nieustannej, wieloletniej

${ }^{13}$ J. Tomaszewska, Dyskryminacja ze względu na płeć, w: Dyskryminacja ze względu na płeć i jej przeciwdziałanie, Publikacja Pełnomocnika Rządu do Spraw Równego Statusu Kobiet i Mężczyzn, Warszawa 2004.

${ }^{14}$ M. Fuszara (red.), Kobiety $w$ Polsce na przełomie wieków: nowy kontrakt płci?, ISP, Warszawa 2002.

${ }^{15} \mathrm{~K}$. Arcimowicz, Wizerunek ojca w polskich mediach na przełomie XX $i$ XXI wieku, w: M. Fuszara (red.), Nowi mężczyźni: zmieniajace się modele męskości we współczesnej Polsce, Trio, Warszawa 2008 , s. 28.

${ }^{16}$ Ibidem, s. 29. 
walki jest coraz częściej zauważane. Oczywiście nie wszędzie i nie zawsze, ale chociażby organizowany corocznie plebiscyt na Firme przyjazna mamie $e^{17}$ świadczy o dostrzeżeniu problemu młodych kobiet związanego z godzeniem życia zawodowego z rodzinnym. Włączenie macierzyństwa do dyskursu publicznego, jak również do codziennego funkcjonowania zwykłych przedsiębiorstw, sprawia, że problem ten przestał być tematem tabu w miejscu pracy. Niestety z ojcostwem nie jest tak samo. Mężczyzna w miejscu pracy w dalszym ciagu częściej postrzegany jest jako żywiciel rodziny (breadwinner) niż rodzic-opiekun (carer). Mężczyznę można obarczyć dodatkowymi obowiązkami - na pewno ma czas, jest ambitny i zależy mu na dodatkowym wynagrodzeniu.

Istnieje wiele przykładów pochodzacych z życia codziennego, które dowodza, że temat ojcostwa w pracy jest nieobecny, np. oferowanie pracownikom wczasów dla matki i dziecka (a nie dla rodzica/ojca i dziecka), miejsca w autobusie dla matki i dziecka czy chociażby Centrum Zdrowia Matki, Dziecka i Młodzieży. Świadczy to jedynie o tym, że w sferze publicznej matka i dziecko stanowią jedność i ze względu na to należy ich chronić, pomagać im czy ułatwiać życie. Niestety trudno w tym dostrzec miejsce dla ojca.

Wśród pracodawców w dalszym ciagu dominuje przekonanie, że pracownik-mężczyzna jest dyspozycyjny i elastyczny. Z góry zakłada się, że problem godzenia życia zawodowego z rodzinnym dotyczy wyłącznie kobiet i w związku z tym to właśnie mężczyznom łatwiej niż kobietom jest znaleźć pracę. Konsekwencja tego sa szeroko opisane nierówności kobiet i mężczyzn na rynku pracy (biorąc pod uwagę np. ścieżki awansu, segregację zawodowa, pay gap itp.).

Dlatego w sposób szczególny należy promować tych przedsiębiorców, którzy realizują politykę równościową w swoich firmach. Polityka równych szans $\mathrm{w}$ miejscu pracy jest w Polsce pojęciem nowym i stosunkowo mało znanym. W ciagu ostatnich kilku lat obserwuje się jednak wzrost zainteresowania kwestią równości płci w środowisku biznesu. Dzieje się tak m.in. dlatego, że zbudowanie w przedsiębiorstwie atmosfery szacunku i otwartości, zapobieganie dyskryminacji, a także zapewnienie, że każda i każdy ma równe szanse rozwoju i samorealizacji, zaczęło się pracodawcom opłacaćc ${ }^{18}$. Z polityką równościową w sposób bezpośredni łączy się dość nowa w polskich realiach strategia zarządzania personelem określana mianem zarządzania różnorodnością (diversity management). Podstawowym założeniem tego podejścia jest przekonanie, że zróżnicowanie personelu stanowi zasób przedsiębiorstwa, który w określonych warunkach może stać się źródłem korzyści biznesowych i zysków. Zarządzanie różnorodnością służy osiągnięciu konkretnych i wymiernych efektów. Główne motywacje do wdrażania rozwiązań z zakresu zarządzania różnorodnością to osiaganie zysku, budowa przewagi konkurencyjnej i osiaganie celów firmy ${ }^{19}$.

${ }_{17}$ Zob. http://firmaprzyjaznamamie.pl/FirmaPrzyjaznaMamie/0,0.html (dostęp: 3.04.2013).

${ }_{18}$ M. Rawłuszko, Polityka równych szans a zarzadzanie różnorodnościq, w: P. Kaczmarek, E. Gross-Gołacka (red.), Przewodnik dobrych praktyk „Firma równych szans”, Warszawa 2007, s. 26-30.

${ }^{19}$ Ibidem, s. 27. 
Przyjęcie takiej strategii zarządzania personelem pozwala pracodawcom dostrzec, że zarówno kobiety, jak i mężczyźni moga mieć problemy z osiaganiem work-life balance. Wdrożenie podstawowych zasad zarządzania różnorodnością w przedsiębiorstwie pozwala zyskać większą lojalność osób zatrudnionych, większą kreatywność zespołów, innowacyjność działania czy lepszą odporność firmy na kryzys, wpływa pozytywnie na kształtowanie się kultury organizacyjnej w firmie oraz w sposób znaczaccy zwiększa jej efektywność.

\section{MODEL RODZINY}

A jak widza to sami młodzi ludzie? Najnowsze badania dotyczace preferowanego modelu rodziny przeprowadzone przez $\mathrm{CBOS}^{20}$ dowodza, że prawie połowa Polaków (48\%) uważa, że najbardziej pożądany dla rodziny jest tzw. model partnerski, w którym partnerzy w równym stopniu poświęcają się pracy i obowiązkom domowym. Nieco ponad jedna czwarta badanych (27\%) popiera tzw. model mieszany, kiedy to obydwoje rodzice pracuja, ale to mężczyzna poświęca więcej czasu pracy zawodowej, a kobieta łączy pracę zawodową z obowiązkami rodzinnymi (prowadzenie domu i wychowanie dzieci - dual earner - female double burden). Co piąty badany (22\%) uważa natomiast, że praca zawodową i aktywnością w sferze publicznej powinien w całości zajmować się mężczyzna, a kobieta ma ograniczyć swoją aktywność do sfery prywatnej (model tradycyjny). Wreszcie zaledwie 1\% badanych jest zwolennikiem tzw. modelu odwróconego, w którym to partnerka pracuje i utrzymuje rodzinę, a partner przejmuje obowiązki domowe.

W literaturze przedmiotu możemy znaleźć wiele klasyfikacji czy typologii rodziny, z których na użytek niniejszego artykułu najbardziej adekwatna wydaje się typologia ekonomicznych modeli rodziny według Arnlaug Leiry ${ }^{21}$, w której kryterium podziału jest nastawienie wobec pracy zarobkowej kobiety. Możemy więc wyróżnić: model tradycyjny - który opiera się na jedynym żywicielu rodziny w postaci mężczyzny oraz na nieodpłatnej pracy kobiety w domu, model drugi - jest tak naprawdę niewielką modyfikacją pierwszego, gdyż zakłada zawodowe zaangażowanie kobiety jedynie w niepełnym wymiarze czasu pracy. Model trzeci - zbliżony jest do opisanego wcześniej modelu mieszanego, gdyż pracujący mąż pomaga w nim pracującej zawodowo w pełnym wymiarze czasu kobiecie w wypełnianiu obowiązków domowych, ale odpowiedzialność za sprawne funkcjonowanie rodziny w tej sferze ponosza przede wszystkim kobiety (dual earner - female double burden). Wreszcie czwarty model partnerski - zakłada równość w zakresie zaangażowania zawodowego i rodzinnego małżonków (dual earner - dual-career family), każde z małżonków ma w nim jednakową szansę na realizację zarówno kariery zawodowej, jak i możliwość samorealizacji.

${ }^{20}$ Potrzeby prokreacyjne oraz preferowany i realizowany model rodziny. Raport z badań. 2012, http://www.cbos.pl/SPISKOM.POL/2012/K_061_12.PDF (dostęp: 22.04.2013).

21 A. Leira, op. cit., s. 5. 
Na przestrzeni ostatnich 15 lat obserwujemy w Polsce wyraźny wzrost akceptacji dla modelu partnerskiego (37\% - 1997) przy jednoczesnym zmniejszaniu się poparcia dla modelu tradycyjnego (38\% - 1997). Interesujaccy jest też prawie ciagły wzrost uznania dla modelu mieszanego ( $23 \%-1997)$. Konsekwencją przyjęcia modelu mieszanego jest w praktyce całkowite obarczenie kobiety koniecznościa godzenia życia zawodowego i rodzinnego, przy niewielkim wkładzie mężczyzn. Model mieszany można więc sparafrazować w ten sposób: pozwalamy kobiecie pracować zawodowo, ale sama musi liczyć się z konsekwencjami konieczności wypełniania wielu ról.

Jeżeli jednak weźmiemy pod uwagę zmienną płci, to okaże się, że kobiety częściej niż mężczyźni wskazują na model partnerski jako bardziej pożądany (54\% vs. 41\%), z kolei mężczyźni częściej deklarują poparcie dla modelu tradycyjnego (27\% przy 18\% kobiet). Akceptacja dla modelu partnerskiego jest również zależna od poziomu wykształcenia - im poziom jest wyższy, tym akceptacja jest większa.

Jak wygląda jednak w praktyce realizacja tych deklaracji. W 2010 r. CBOS zapytał respondentów o rzeczywisty podział ról i obowiązków w ich rodzinach. Okazało się, że tylko 28\% respondentów w praktyce realizuje model partnerski (kobieta i mężczyzna w równym stopniu poświęcają się pracy i obowiązkom domowym). Natomiast model mieszany wdraża zbliżona do deklaracji liczba respondentów (26\%). Co piąty badany (20\%) przyznaje, że to mężczyzna jest odpowiedzialny za zapewnienie rodzinie odpowiednich środków finansowych służących zaspokojeniu potrzeb, a kobieta zajmuje się domem i wychowaniem dzieci. Co ciekawe, model odwrócony realizowany jest w rodzinach $3 \%$ badanych. Można jednak przypuszczać, że w większości przypadków sytuacja taka jest raczej wymuszona czynnikami ekonomicznymi (kobieta zarabia więcej, ma lepszą pracę), niż wynika z pełnej akceptacji dla takiego modelu (dla przypomnienia 1\%). Co ósmy badany (13\%) deklaruje, że żaden z parterów nie pracuje zawodowo. Porównując te dane z danymi z 2006 r., dostrzegamy wzrost deklaracji dotyczących realizacji w praktyce modelu partnerskiego.

Nie możemy jednak zaprzeczyć, że są mężczyźni, którzy nie chcą realizować stereotypowo przypisanego im tradycyjnego modelu ojcostwa i rodziny (ojciec nieobecny, ojciec żywiciel rodziny), którzy również nie są zwolennikami modelu mieszanego - najbliższy jest im model ojca zaangażowanego w opiekę nad dzieckiem (model partnerski czy nawet model odwrócony) i sprawy domu. Dane wyraźnie pokazuja, że przynajmniej połowa badanych uważa, że kobiety i mężczyźni powinni mieć takie same prawa i obowiązki. Czy wobec tego pracodawcy dostrzegają zmiany, jakie zachodzą we współczesnej rodzinie? Czy dostrzegaja, że coraz więcej młodych ludzi, którzy dopiero rozpoczynają swoja karierę zawodową oraz życie rodzinne - chce inaczej pokierować obiema tymi sferami?

Ojcostwo w zakładzie pracy jest tematem tabu. Przywileje związane z rodzina sa implicite skierowane do kobiet (elastyczne zatrudnienie, wydłużony urlop macierzyński itp.). Chociaż może również być tak, że to mężczyźni nie dostrzegaja w tym zakresie potrzeby żadnych działań. Jak podkreślaja autorzy raportu z badań Godzenie ról rodzinnych $i$ zawodowych kobiet $i$ męż- 
czyzn, mężczyźni, gdy oceniają różne formy wsparcia w zakresie godzenia ról zawodowych z rodzinnymi, automatycznie odnosza je do sytuacji swoich partnerek, w ogóle nie dopuszczając myśli, że to oni mogliby być ich beneficjentami $^{22}$. Uznanie prawa mężczyzny do współdzielenia opieki nad dzieckiem w równym stopniu, co kobieta, jest nie tylko punktem wyjścia stworzenia bardziej partnerskich relacji w rodzinie, ale też kluczem do długotrwałych przemian demograficznych i ekonomicznych.

Mimo że problem godzenia życia zawodowego i rodzinnego w największym stopniu dotyczy matek, to działania podejmowane przez pracodawcę powinny dotyczyć całej rodziny. Dlaczego? Jest to bowiem wymóg współczesnego świata, doceniaja to obecni i potencjalni pracownicy w firmach, które to stosuja, doceniają to eksperci, dzięki czemu firma zyskuje lepszy wizerunek. Jest to wreszcie zgodne z zasadą równości płci i sprzyja realizacji strategii zarządzania różnorodnościa.

\section{ELASTYCZNA ORGANIZACJA PRACY}

Jak w praktyce wyglądają ułatwienia związane z godzeniem życia prywatnego i zawodowego? ${ }^{23} \mathrm{~W}$ dążeniu do osiagania work-life balance szczególnie ważne wydają się elastyczne rozwiązania w pracy: elastyczne godziny pracy, możliwość swobodnego korzystania z tzw. banku godzin, ruchome godziny rozpoczynania i kończenia pracy bądź możliwość wzięcia dnia wolnego w nieprzewidzianych, nagłych sytuacjach rodzinnych. Czy pracodawcy wychodzą naprzeciw oczekiwaniom rodziców? Szczegółowych danych uwzględniających płeć zatrudnionych dostarcza GUS.

Okazuje się, że mężczyźni mają większe niż kobiety możliwości skorzystania z elastycznej organizacji pracy. W odniesieniu do czasu pracy - aż 89,1\% kobiet deklaruje stałe godziny rozpoczynania i kończenia pracy przy 86\% mężczyzn. Kolejne elastyczne rozwiązanie, tzw. bank godzin (ustalona jest łączna liczba godzin do przepracowania w miesiącu i w skali miesięcznej godziny pracy są rozliczane) również jest częściej dostępny w miejscu pracy mężczyzn (5,2\% pracowników najemnych) niż kobiet (3,9\%). Możliwość swobodnego wyboru godziny rozpoczynania i kończenia pracy deklaruje ok. 5,7\% pracowników najemnych - i podobnie jak we wcześniejszych przypadkach, częściej sa to mężczyźni niż kobiety $(6,3 \%$ wobec $5,0 \%)$.

Warto jednak zauważyć, że przytaczane dane GUS-u dotyczą możliwo ści, a nie realnego korzystania z tych form zatrudnienia - mówią jedynie o tym, że 12,6\% mężczyzn ma szansę uelastycznić swoją pracę, żeby lepiej godzić życie zawodowe i rodzinne, niestety nic nie mówią na temat rzeczywistego wykorzystania tych możliwości.

${ }_{22}$ M. Sochańska-Kawiecka, Z. Kołakowska-Seroczyńska, A. Morycińska, Godzenie ról rodzinnych $i$ zawodowych kobiet $i$ mężczyzn. Raport z badań jakościowych i ilościowych, Warszawa 2009.

${ }^{23}$ Praca a obowiazki rodzinne 2010, GUS, Warszawa 2012. 
Możliwości dostosowania czasu pracy do potrzeb związanych z życiem rodzinnym zależą także od wykonywanego zawodu. Na podstawie danych GUS-u możemy zauważyć, że największe trudności z pogodzeniem życia zawodowego i rodzinnego mają więc pracownicy wykonujący zawody należące do grup: pracowników biurowych, robotników przemysłowych i rzemieślników oraz operatorów i monterów maszyn i urządzeń. Warto przy tym zaznaczyć, że w pierwszej grupie dominuja kobiety $(67,7 \%$ ogółu zatrudnionych w tej grupie), natomiast w pozostałych dwóch zdecydowanie przeważają mężczyźni (odpowiednio 85,7\% i 86,3\%). Tak więc na podstawie tylko i wyłącznie dostępności elastycznych form zatrudnienia $\mathrm{w}$ danych grupach zawodowych trudno jednoznacznie wskazać, kto - kobiety czy mężczyźni - ma większe trudności z godzeniem sfery rodzinnej i zawodowej.

Analiza danych dotyczacych faktycznie przepracowanego czasu i organizacji pracy pokazuje, że pomimo tego, że mężczyźni maja większe możliwości uelastycznienia swojej pracy, to korzystają z tej możliwości rzadziej niż kobiety. Świadczy o tym wiele danych. Jedna z nich jest przeciętna liczba godzin przepracowanych $\mathrm{w}$ tygodniu: 40,4 godziny dla mężczyzn i 36,1 dla kobiet $^{24}$. Jeżeli uwzględnić rozkład pracujących według liczby godzin faktycznie przepracowanych $\mathrm{w}$ tygodniu, to kobiety dwa razy częściej niż mężczyźni pracują w zmniejszonej (i to znacznie) liczbie godzin. Poniższe dane uwzględniają tylko pracowników najemnych (czas pracy właścicieli firm i pracujących na własny rachunek jest dłuższy - co wynika ze specyfiki tej pracy). Zatem od 1 do 19 godzin tygodniowo - pracuje 4,5\% kobiet (wobec $2,1 \%$ mężczyzn), od 20 do 29 godzin - 10,2\% kobiet (5,5\% mężczyzn), 30-39 godzin pracuje 12,5\% kobiet i 10,2\% mężczyzn. Natomiast od 40 do 49 godzin pracuje zbliżony odsetek kobiet $(63,4 \%)$ i mężczyzn $(67,7 \%)$, choć widać, że powoli ta tendencja się odwraca. Znaczące różnice pojawiają się w odniesieniu do pracy powyżej 50 godzin. Tak długi tydzień pracy deklaruje 11,3\% mężczyzn i „zaledwie” 2,6\% kobiet. Powyższe dane potwierdzają więc wcześniejsze ustalenia: mężczyźni częściej niż kobiety pracuja dłużej, zostają po godzinach pracy i wykonuja dodatkowe czynności. Co dziesiąty pracujący mężczyzna pracuje tygodniowo dłużej, niż wynika to z podstawowego czasu jego pracy. Może to m.in. wynikać właśnie z tego, że pracodawcy uważaja, że mężczyźni częściej niż kobiety powinni być obarczani dodatkowymi obowiązkami, gdyż problem godzenia pracy zawodowej i rodzinnej ich nie dotyczy lub dotyczy w mniejszym stopniu.

Interesujące są również dane dotyczące zatrudnienia w niepełnym wymiarze czasu pracy. W IV kwartale 2009 r. kobiety dwukrotnie częściej niż mężczyźni pracowały w zmniejszonym wymiarze czasu pracy $(11,2 \%$ kobiet wobec 5,6\% mężczyzn). Jeżeli chodzi o przyczyny takiej pracy, to zarówno wśród mężczyzn, jak i wśród kobiet najczęściej wybieraną odpowiedzią było: „pracującemu odpowiada taki wymiar czasu". Mężczyźni dużo częściej niż kobiety deklarowali „chorobę i/lub niepełnosprawność” jako powód zmniejszonego czasu pracy. Kobiety natomiast częściej wskazywały na „niemożność znalezienia pracy w pełnym wymiarze”. „Opieka nad dziećmi lub osobą niepełnosprawną" była przyczyną wskazywaną jedynie przez kobiety.

\footnotetext{
${ }^{24} \mathrm{Na}$ podstawie GUS (dostęp: 17.04.2013).
} 
Przy omawianiu problematyki łączenia pracy zawodowej z obowiązkami rodzinnymi szczególną uwagę należy zwrócić na sytuację rodziców w kontekście sprawowania opieki nad dziećmi do lat 8. Wiąże się ona często z koniecznością całkowitej lub częściowej rezygnacji z pracy zawodowej bądź też z korzystaniem z urlopu wychowawczego. Warto zaznaczyć, że w Polsce prawo do urlopu wychowawczego mają zarówno kobiety, jak i mężczyźni i obejmuje ono także prawo do zmniejszenia wymiaru czasu pracy. Jednak w praktyce, jak pokazują dane GUS-u, mężczyźni nie korzystają z tego prawa - gdyż tylko co setny mężczyzna $(1,2 \%)$ opiekujący się dzieckiem do lat 8 (na podstawie badania z 2010 r.) skorzystał z prawa do urlopu wychowawczego w wymiarze co najmniej 1 miesiąca. Dla porównania - w przypadku kobiet było to $38,4 \%$ uprawnionych. Mała liczba kobiet i znikoma liczba mężczyzn, którzy decydują się na urlop wychowawczy, wynika m.in. z trudnej sytuacji na rynku pracy. Potwierdzają to informacje uzyskane z Centrali ZUS-u w Warszawie. Liczba pracowników, którzy skorzystali z pełnego 36-miesięcznego wymiaru urlopu wychowawczego w 2009 r., wyniosła 10,9 tys. pracowników, w 2010 r. - 7,5 tys. pracowników, natomiast w 2011 r. liczba ta zmalała do 3,9 tys. pracowników ${ }^{25}$.

Pomysłem państwa na większe włączenie mężczyzn w życie rodzinne było ustanowienie urlopu związanego z urodzeniem dziecka tylko dla ojców. Jednak analizując dane dotyczące wykorzystania urlopu ojcowskiego ${ }^{26}$, widzimy, że wciąż wykorzystuje go znikoma liczba mężczyzn. W 2010 r. (pierwszy rok, w którym urlop ten przysługiwał) skorzystało z niego zaledwie 17,2 tys. ojców ${ }^{27}$, rok później było to 14,9 tys. W obydwu tych latach wymiar urlopu wynosił tydzień. W 2012 r., kiedy podwojono czas jego trwania, znacznie więcej ojców (28,6 tys.) zdecydowało się spędzić czas z dzieckiem. W dalszym ciagu jednak niewielka liczba ojców decyduje się wykorzystać przysługujące im prawo (biorąc pod uwagę, że np. w 2011 r. liczba urodzeń wyniosła aż 391 tys.). Przyczyn należy szukać z jednej strony w niewiedzy ojców na temat przysługującego im dodatkowego urlopu, a z drugiej strony może to wynikać ze stereotypowego postrzegania roli ojca („nie wypada” brać urlopu) czy oczekiwań pełnej dyspozycyjności ze strony pracodawców.

Alternatywą dla urlopu wychowawczego jest zmniejszenie wymiaru czasu pracy umożliwiające łączenie pracy zawodowej z opieką nad dzieckiem. Dane GUS-u pokazuja, że $12,7 \%$ osób opiekujących się dzieckiem do lat 8 deklarowało zmniejszenie wymiaru czasu pracy na okres co najmniej 1 miesiacca. Dane te zasadniczo różnią się ze względu na płeć - w przypadku kobiet było to $22,5 \%$, natomiast wśród mężczyzn zaledwie 3,0\%. W odniesieniu do rodziców, którzy zrezygnowali z pracy, w celu opieki nad dzieckiem do lat 8 (przy czym rezygnacja z pracy musiała być spowodowana opieką nad dzieckiem i musiała trwać przynajmniej przez miesiąc) ponownie częściej były to kobiety $(9,8 \%)$ niż mężczyźni (1,1\%).

\footnotetext{
${ }^{25} \mathrm{Na}$ podstawie danych ZUS.

${ }^{26}$ Urlop ten przysługuje na podstawie art. 182 Kodeksu pracy.

$27 \mathrm{Na}$ podstawie danych ZUS.
} 
Jeżeli chodzi o uwzględnienie specyfiki zawodowej, to okazuje się, że grupa zawodowa, w której mężczyźni najczęściej zmniejszali wymiar czasu pracy w celu opieki nad najmłodszym dzieckiem do lat 8 byli rolnicy, ogrodnicy, leśnicy i rybacy $(5,4 \%)$. Najrzadziej sytuacja ta wystapiła (w odniesieniu do mężczyzn) w przypadku pracowników biurowych (1,3\%).

\section{OJCIEC W DOMU, MATKA W PRACY?}

Na podstawie przedstawionych wyżej danych można powiedzieć, że problem godzenia życia zawodowego i rodzinnego to problem kobiet. To one częśsciej rezygnują z pracy, korzystają z bezpłatnych urlopów wychowawczych czy ograniczają swoją pracę zawodowa. Otwarte pozostaje pytanie o przyczyny takiego stanu rzeczy. Dlaczego to nie mężczyźni zostają w domu, chociaż maja takie same możliwości jak kobiety, a w niektórych kwestiach nawet lepsze (np. w odniesieniu do dostępności elastycznych form organizacji pracy)?

Biorąc pod uwage sytuację gospodarcza, odpowiedź narzuca się sama - sa to kwestie finansowe. W Polsce (podobnie jak w innych krajach UE i świata) wciąż występują znaczące różnice w zarobkach między kobietami i mężczyznami (pay gap), które wynoszą od kilkunastu do nawet dwudziestu kilku procent. Jeżeli więc to mężczyzna zarabia więcej niż kobieta - to z ekonomicznego punktu widzenia - rozsądniejsza wydaje się decyzja, żeby to kobieta ograniczyła swoją karierę zawodową. Jednak takie tłumaczenie jest coraz częściej błędne. Dlaczego? Po pierwsze, jest coraz więcej kobiet, które zarabiają tyle samo, a nawet lepiej niż ich partnerzy/mężowie. Po drugie, coraz częściej mężczyźni chcą wkraczać do sfery prywatnej, chca opiekować się swoimi dziećmi. Stereotypowe patrzenie na rodzinę, w której mężczyzna ma realizować się w pracy zawodowej, a kobieta w życiu rodzinnym, jest więc nie zawsze zgodne z rzeczywistościa.

Odrzucając więc kwestie ekonomiczne, druga przyczyna, dla której to nie mężczyźni zostają w domu, by opiekować się dziećmi, może wynikać z postawy samych kobiet. To one w jakiejś części są odpowiedzialne za to, że mężczyzna nie realizuje się w sferze prywatnej. Wynika to z jednej strony z oczywistych uwarunkowań biologicznych, a z drugiej - z pewnych utartych stereotypów, mówiących, że to matka „powinna” zajmować się dzieckiem w najmłodszych latach. Takim postawom sprzyja wydłużenie urlopów rodzicielskich do jednego roku. W większości przypadków (pomimo możliwości podziału tego urlopu) to kobiety wykorzystują go w całości. W związku z tym wielu matkom może wydawać się, że są trochę „lepszym rodzicem” niż ojciec, ponieważ dużo więcej wiedzą o swoich dzieciach, lepiej znaja ich upodobania i potrzeby niż partnerzy/mężowie. Co ciekawe, te same matki, które nie dowierzają do końca swoim partnerom, bez oporów zostawiają dziecko pod opieką babć czy obcych opiekunek (ale w dalszym ciagu kobiet). Jednocześnie jednak cierpia na tzw. syndrom matczynej winy ${ }^{28}$, który jest efektem konfliktu ról doświad-

28 J. Ostrouch, Kobieta nieustannie (u)wiktana, „Acta Universitstis Nikolai Copernici. Socjologia Wychowania” XVI, z. 378, Toruń 2006, s. 121-128. 
czanego przez kobiety. Innymi słowy, to efekt dysonansu między rolą przypisana a wybrana. Charakteryzuje się on ciagłym poczuciem zaniedbywania poszczególnych sfer życia i wiąże się z brakiem wystarczającej ilości czasu na zrealizowanie wszystkich podjętych zobowiązań: zawodowych, związanych z opieką nad dziećmi, z ich wychowaniem, prowadzeniem domu, ale również wynikających z chęci samorealizacji i zaspokajania osobistych potrzeb.

Mówiąc o syndromie matczynej winy, warto zauważyć, że literatura przedmiotu milczy na temat syndromu ojcowskiej winy. Może jest to obszar wart głębszej analizy: skoro zakładamy, że istnieją mężczyźni, którzy chcą angażować się w życie prywatne swoich rodzin i równolegle realizować się zawodowo to można też przyjąć, że przynajmniej niektórzy z nich będą doświadczali poczucia winy spowodowanej niemożnością spełnienia wszystkich oczekiwań i zaspokojenia wszystkich potrzeb.

Betty Friedan zauważa, że ten nacisk na sukces w sferze zawodowej jest pochodna socjalizacji i uwarunkowań kulturowych, którym poddawani sa mężczyźni ${ }^{29}$. Praktycznie od urodzenia mężczyzna jest socjalizowany do pracy, a istotnym elementem socjalizacji jest nastawienie na samowystarczalność, aby w przyszłości mógł utrzymać rodzinę. W efekcie większość mężczyzn planuje i realizuje kariere zawodową według bardzo stresującego schematu. Dzięki sukcesom zawodowym (dostęp do władzy, uzyskiwane dochody) wzrasta prestiż i samoocena. To przekłada się na zyskiwanie akceptacji otoczenia, czemu towarzyszy często chęć obdarowywania najbliższych. Realizowane postawy szczodrości (prezenty, wakacje) sa wpisane w męską socjalizację, a ta postawa jest możliwa dzięki zarabianym pieniądzom. Chłopcu od najmłodszych lat wpaja się, że powinien pracować na rodzinę, dokonywać wyborów i panować nad każdą sytuacją. Jednak w praktyce bycie mężem i ojcem w ostatnich latach bardzo odbiega od stabilności, pociagając za soba wiele dodatkowych wymagań, dotyczących zarówno naszych sił fizycznych, jak i psychicznych ${ }^{30}$. Tożsamość mężczyzny jest budowana w oparciu o pracę zawodowa. To, jakim się jest mężczyzną i ojcem, w dużej mierze zależy od tego, jaką się pracę wykonuje. Dlatego próby wyjścia mężczyzn ze sfery publicznej do prywatnej często kończą się obniżeniem statusu społecznego i zmianą zajmowanej pozycji.

\section{PODSUMOWANIE}

Trzeba pamiętać, że określenie work-life balance odnosi się nie tylko do kwestii związanych $\mathrm{z}$ rodzicielstwem. Istnieje całe spektrum aktywności, które należy uwzględnić przy godzeniu tych dwóch sfer. Począwszy od hobby, przez spotkania towarzyskie, a na zwykłym odpoczynku kończąc. Wiąże się to generalnie z czasem wolnym od pracy zarobkowej. Dane OECD pokazuja, że kobiety mają mniej czasu wolnego niż mężczyźni, gdyż czas poza praca spędzają w domu, wykonując różne obowiązki (prace związane z prowadze-

29 B. Friedan, The Fountain of Age, New York 1993, s. 174.

${ }^{30}$ G. Witkin, Stres męski, Rebis, Poznań 2000, s. 260. 
niem gospodarstwa domowego, opieka nad dziećmi). Obliczono, że kobiety średnio wypełniają obowiązki domowe dwie i pół godziny dziennie dłużej niż mężczyźni. Co więcej, można zauważyć, że wśród tych kobiecych powinności częściej znajdują się czynności bardziej wyczerpujące i mniej przyjemne (np. w odniesieniu do opieki nad dziećmi kobiety częściej deklarują takie rutynowe czynności, jak karmienie, kapanie, ubieranie, podczas gdy mężczyźni wskazuja na czytanie czy zabawę z dziećmi) ${ }^{31}$.

W praktyce dnia codziennego coraz częściej mówi się o work-life balance. Jednak w większości przypadków dotyczy to kobiet. Wprawdzie patrzy się na nie z pobłażaniem, czasem z wyrzutem, ale akceptuje spóźnienia, czy wcześniejsze wyjścia, niekończące się zwolnienia z pracy czy nagłe urlopy z powodów rodzinnych. Tych samych „niepisanych” praw nie gwarantuje się jednak mężczyznom. Mężczyzna, który zostaje w domu z chorym dzieckiem, jest bardzo rzadko spotykanym zjawiskiem.

Jak zauważa Thomas Gesterkamp, mężczyzna, który chce wyjść wcześniej $\mathrm{z}$ pracy z powodu urodzin dziecka, traktowany jest jako gorszy pracownik, a jego zachowanie uznaje się za nienaturalne (zwłaszcza jeżeli pracuje w silnie zmaskulinizowanym środowisku) ${ }^{32}$. Z tego powodu ojcostwo $\mathrm{w}$ miejscu pracy jest w znacznej mierze niewidoczne. Pracodawcy bowiem zakładaja, że życie rodzinne pracowników (mężczyzn) nie powinno w żaden sposób zakłócać przebiegu pracy w firmie.

Peter Doge wskazuje na możliwe reakcje, jakie napotykają w miejscu pracy mężczyźni zorientowani na rodzinę ${ }^{33}$ : zmniejszanie liczby godzin pracy interpretowano jako niesolidarne żądanie, mężczyzna pracujący w niepełnym wymiarze godzin uchodzi za kogoś, kto unika pracy, przełożeni i koledzy nie postrzegają ojcowskich zobowiązań względem rodziny jako uzasadnionego powodu, by zawodowe zaangażowanie przyhamować na jakiś czas. Badani przez niego mężczyźni opowiadali o permanentnej presji tłumaczenia się (gdy nie można zostać po godzinach, gdyż trzeba odebrać dziecko z przedszkola).

Stereotypy, które zamykają kobiety w domu, wypychają z niego mężczyzn czyniąc szkodę zarówno jednym, jak i drugim. Zmiany w prawie wprowadzające urlop rodzicielski tylko z pozoru dają większe możliwości rodzicom. Z perspektywy rodziny bowiem decyzja o tym, kto powinien zajmować się nowo narodzonym dzieckiem, jest oczywista: to kobieta zostanie w domu, gdyż cała rodzina mniej na tym straci finansowo i mniej ryzykuje utratą pracy. Tak więc w praktyce oznaczać to będzie de facto pogorszenie sytuacji kobiet na rynku pracy, natomiast w przypadku mężczyzn niewiele się zmieni.

Słuszny więc wydaje się postulat, by wzorem krajów skandynawskich wprowadzić obowiązkowy, kilku-, a nawet kilkunastotygodniowy urlop tylko dla ojców, który niewykorzystany - przepadałby. Zmniejszyłoby to wówczas

${ }^{31}$ V. Miranda, Cooking, Caring and Volunteering: Unpaid Work Around the World. OECD Social, Employment and Migration Working Papers 116 (2011), OECD Publishing, Paris.

${ }^{32}$ T. Gesterkamp, Ojcowie a kariera: sposób na uzyskanie równowagi, Instytut Wydawniczy PAX, Warszawa 2009, s. 83.

${ }_{33}$ P. Doge, Geschlechterdemokratie als Mannlichkeitskritik. Blockaden und Perspektiven einer Neugestalltung des Geschlechterverhaltnisses, Bielefeld 2001, za: T. Gesterkamp, Ojcowie a kariera: sposób na uzyskanie równowagi, Instytut Wydawniczy PAX, Warszawa 2009, s. 71-72. 
chociaż trochę nierównowagę sytuacji kobiet i mężczyzn na rynku pracy. Dodatkowo zaowocowałoby to większym włączeniem się mężczyzn w proces wychowania dziecka i tym samym ich pełniejsze wejście do sfery prywatnejnie jak dotąd jedynie w charakterze zewnętrznego obserwatora, tylko jako pełnoprawnego uczestnika. Dzięki urlopowi wyłącznie dla ojca Polska zrobiłaby ogromny krok naprzód w kierunku przełamywania stereotypów, że małemu dziecku potrzebna jest wyłącznie matka (w związku z tym urlop dla ojca jawi się jako strata czasu), ale równie ważny w rozwoju jest ojciec.

dr Dominika Polkowska

Uniwersytet Marii-Curie Skłodowskiej w Lublinie

dominika.polkowska@umcs.pl

MEN IN THE PRIVATE SPHERE - A FICTION OR REALITY?

Summary

The problem of reconciling work and family life has always been the women's problem. They often gave up work, stayed home on maternity leave or found only part-time employment. Is there a place for men in the feminised private sphere? Stereotypes that lock women at home and push men out of home cause damage to both groups. As the available data and results of earlier analyses show that men, at least officially, do have the same opportunities as women to take advantage of, for example: the availability of flexible forms of employment, but still very few of them do that. For this reason, men are still more likely to be seen as breadwinners than carers. The situation is exacerbated by the fact that in most cases fatherhood in the workplace is not to be openly demonstrated. Employers assume that the family life of workers (men) should not interfere with their work in the company. 
Copyright of Journal of Law, Economics and Sociology is the property of Faculty of Law and Administration of Adam Mickiewicz University in Poznan and its content may not be copied or emailed to multiple sites or posted to a listserv without the copyright holder's express written permission. However, users may print, download, or email articles for individual use.

Właścicielem praw autorskich do „Ruchu Prawniczego, Ekonomicznego i Socjologicznego” jest Wydział Prawa i Administracji Uniwersytetu im. Adama Mickiewicza w Poznaniu. Zawartość czasopisma nie może być kopiowana, przesyłana do innych stron internetowych bądź zamieszczana na blogach bez pisemnej zgody wydawcy. Niemniej artykuły można drukować, kopiować lub przesyłać w formie elektronicznej na własny użytek. 